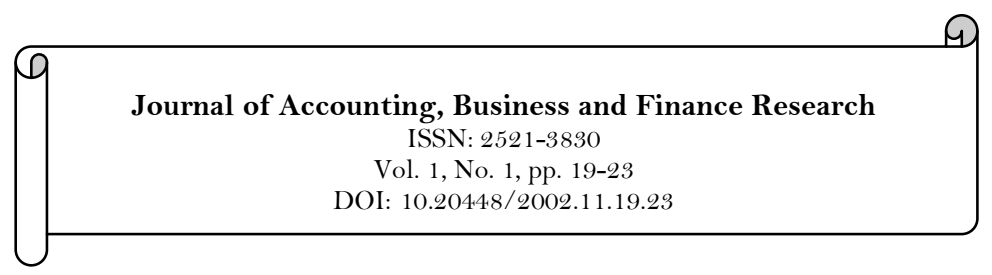

\title{
Implementation of Continuous Auditing for the Public Sector in Nigeria
}

\author{
Jones Osasuyi Orumwense ${ }^{1}$ \\ ${ }^{1}$ Wellspring University, Benin City, Nigeria.
}

\begin{tabular}{|c|c|}
\hline Abstract & \\
\hline $\begin{array}{l}\text { Aims: The main purpose of the study was to access the challenges } \\
\text { the government financial system in Nigeria has undergone in the } \\
\text { recent times and with the aim of proposing a model that could be } \\
\text { used to implement continuous auditing by the Public Sector Audit } \\
\text { Organizations. Study design: Adoption of existing model and survey } \\
\text { using questionnaires. Place and Duration of Study: Nigeria, } \\
\text { 2014.Methodology: The existing continuous auditing models were } \\
\text { studied and the integrated Continuous Auditing, Monitoring and } \\
\text { Assurance Conceptual Model was adopted for use. The model was } \\
\text { tested using data collected using questionnaires. Data was collected } \\
\text { from 1Oo auditors in the Public Sector Audit Organizations. The } \\
\text { Audit Command Language software (a Computer Aided Audit Tool) } \\
\text { and a database system of a government ministry were used to } \\
\text { demonstrate how data can be obtained directly from a client system. } \\
\text { Results: The study found the need for training in the skills necessary } \\
\text { for continuous auditing and the acquisition of Information and } \\
\text { Communication Technology resources and infrastructure were } \\
\text { necessary in realizing continuous auditing. Conclusion: The } \\
\text { Integrated Continuous Auditing, Monitoring and Assurance } \\
\text { Conceptual Mode would offer a good starting point in the } \\
\text { implementation of continuous auditing by the Public Sector Audit } \\
\text { Organization. }\end{array}$ & $\begin{array}{l}\text { Keywords: } \\
\text { Continuous } \\
\text { auditing } \\
\text { Continuous } \\
\text { auditing } \\
\text { Model and implementation of } \\
\text { continuous auditing. }\end{array}$ \\
\hline
\end{tabular}

\section{Introduction}

The Nigeria government financial system has undergone changes with the traditional paper based manual system being replaced with automated system. The traditional source document such as purchase order invoice and cheques previously used for audit evidence are now in electronic form. The change in business process that removes the paper based sources of information requires the creation of new audit procedures. In addition, business transaction have become more complex and thus increased risk exposure such as possibility of fraud and misappropriation of fund. This calls for a more effective audit to migrate these risks. Automation of the audit process would result in greater efficiency, timelines and high quality audits.. The deployment of a continuous auditing system would be an effective audit method of modern business processes.

This research sought to explore the necessary requirements for implementation of continuous auditing by the public sector audit organization to perform audit work electronically with the aim of improving quality reliability and efficiency of audit.

The objective of the study included accessing the level of automation of the business system used in processing transactions, investigating technologies and automated audit tools for continuous auditing.

Several existing models of continuous auditing were studied. A step by step comparison of the selected models identified the key common elements covering technical professional and governance aspect of continuous auditing. These elements were hence proposed for adoption in continuous auditing by the public sector audit organization.

\section{Literature Review 2.1. Continuous Auditing}

According to Canadian Institute of Chartered Accountants and American Institute of Certified Public Accountants Research Report (CICA/AICPA, 1999) Continuous Auditing is "a methodology that enables independent auditors to prove written assurance on a subject matter using a series of auditors' report issued 
simultaneously with, or a short period of time after, the occurrence of events underlying the subject matter". Development of Continuous Auditing over the last 20 years include use of Audit Modules (AM) to capture and evaluate information when predetermined integrity constraints were breached (Groomer \& Murthy, 1989) Continuous process auditing system (CPAS) to deal with the issue surrounding an increasingly paperless audit environment by continuously monitoring and auditing AT and T's billing system (Vasarhelyi \& Halper, 1991) and the joint report on continuous auditing sponsored by the Canadian institute of chartered accountants and American Institute of Certified Public Accountants (CICA/AICPA, 1999).

Advancements in technologies have continued to improve continuous auditing. Auditors therefore need to have proficiency of the emerging technologies required for the automated systems. These technologies include Embedded Auditing Module (EAM) Extensible business Reporting Language (XBRL), Database Technology, Data Warehouse and the Internet. In addition, there are various tools and techniques which aid in analysis of transactions and internal controls. These tools can either be purchases software packages or auditor-designed module. The tools are collectively referred to as Computer Aided Audit Tools and Techniques (Rezaee, Sharbatoghile, Elam, \& McMickle, 2002).

In today's environment, organizations can produce standardized financial information on a real time, online basis. Real time accounting needs real time auditing to provide continuous assurance about the quality of data. This calls for various technical conditions to be present. These includes reliable systems, highly automates continuous audit process and effective links between the audit's firm system and the clients system to enable fast, accurate and secure communication of audit instructions and results (Shields, 1998).

\subsection{Review of Continuous Auditing Models}

Four models of Continuous Auditing were examined as described below.

\subsubsection{Continuous Audit Approach (Rezaee et al).}

This is a conceptual model which describes Continuous auditing Methodology. An optimal Continuous Auditing is one that uses client/server architecture and well enabled data for delivery to audit work stations. The approaches for collection and storage of data include use of an audit data warehouse and audit data marts. In the former approach, a repository for storing transaction data produced by different business System (data warehouse is designed. The data warehouse should be scalable to allow for more data as audit continues. The approach is appropriate for disperses system with varies data formats. The other approach is where audit data marts are used to automate the capture of relevant data and the auditing and reporting processes.

\subsubsection{Model for Secure Continuous Auditing (Onions)}

The model is concerned with three basic data examination areas. These are keystroke level, transaction level and transaction pattern level data. It suggest that in order to guarantee the integrity of accounting information captured in ledgers, it is necessary to monitor all keystrokes and transaction within the system, and then search for patterns in groups of transactions. The keystroke level data examination involves monitoring database utilities and applications for command which could cause fraud or error. These utilities give users ability to update and master files, bypassing the normal safeguards present in the accounting system itself. Transaction level data examination involves auditing and reporting on each transaction at the time of entry, each being treats as isolated entity. This is meant to ascertain whether each transaction meet the set business rules. Transaction pattern level examination involves examining the effects of transaction as a whole over a longer time period. Expert system trawl through stored transactions looking for pattern as defined by business ruler so as to identify transactions which could together result in fraud.

\subsubsection{Continuous Audit Model (Woodroof and Searcy)}

The model was developed and implemented within a debt covenant compliance domain. It therefore relates to a particular business domain and aims to create a working model of continuous auditing. The definition of Continuous Auditing used in this model is "an assurance service, where the time between the occurrence of event underlying the particular subject matter of a client, and the assurance of an auditor's opinion on the fairness of the client's representation of the subject matter is eliminated.

\subsubsection{Integrated Continuous Auditing, Monitoring, and Assurance Conceptual Model}

Continuous Auditing helps auditors to identify and access risks, as well as establish intelligent and dynamic thresholds that respond to changes in the organization. It also supports risk identification and assessment for the entire audit universe, contributing to the development of the annual audit plan as well as the objectives of a specific unit. The focus of continuous auditing ranges from controls-based to risk-bases while the analysis techniques used in it range from the real-time review of transactions to the analysis of trends over time. 


\subsubsection{Comparison of the Four Models}

We made a comparison of the elements among the models as shown in Table 1. The comparison indicated that the Integrated Continuous Auditing, Monitoring and Assurance Conceptual Model is more inclusive as it encompasses a wider scope of continuous auditing which include technical, professional and governance aspects. Hence the model waa proposed for adoption by the Public Sector Audit Organisation. The other models (Rezaee, Onions and Woodroof) are biased towards the technical architecture.

Table-1. Comparison of Four Selected Models.

\begin{tabular}{|c|c|c|c|c|}
\hline Element & $\begin{array}{l}\text { Continuous Audit } \\
\text { Approach (Rezaee } \\
\text { et al) }\end{array}$ & $\begin{array}{l}\text { Model for Secure } \\
\text { Continuous } \\
\text { Auditing (Onions) }\end{array}$ & $\begin{array}{l}\text { Continuous Audit } \\
\text { Model (Woodroof } \\
\text { and Searcy) }\end{array}$ & $\begin{array}{l}\text { Integrated } \\
\text { Continous Auditing } \\
\text { Conceptual Model } \\
\text { (Coderre) }\end{array}$ \\
\hline $\begin{array}{l}\text { Accuracy } \\
\text { (Fraud and } \\
\text { error) } \\
\text { within } \\
\text { transactions }\end{array}$ & $\begin{array}{l}\text { Standardized audit } \\
\text { tests are built into } \\
\text { audit data marts. } \\
\text { They run either } \\
\text { continuously or at } \\
\text { predetermined } \\
\text { times. These gather } \\
\text { evidence and then } \\
\text { generate the } \\
\text { relevant reports }\end{array}$ & $\begin{array}{l}\text { Transactions are } \\
\text { checked both at } \\
\text { time of entry and } \\
\text { later }\end{array}$ & $\begin{array}{l}\text { Rule-based detection } \\
\text { by digital agents }\end{array}$ & $\begin{array}{l}\text { Real-time review of } \\
\text { transactions to the } \\
\text { analysis of trends } \\
\text { over time. }\end{array}$ \\
\hline $\begin{array}{l}\text { Reliability } \\
\text { of internal } \\
\text { control } \\
\text { system }\end{array}$ & CAATS are used & $\begin{array}{l}\text { Parsing of } \\
\text { keystrokes to detect } \\
\text { database } \\
\text { management } \\
\text { utilities }\end{array}$ & $\begin{array}{l}\text { Adapt and apply } \\
\text { SYSTRUST } \\
\text { Principles }\end{array}$ & CAATS ARE USED \\
\hline Real-time & $\begin{array}{l}\text { Real-time } \\
\text { processing is the } \\
\text { aim for this system }\end{array}$ & $\begin{array}{lr}\text { All } & \text { proposed } \\
\text { systems } & \text { run in } \\
\text { parallel } & \text { with } \\
\text { operational } & \text { systems } \\
\text { in real-time } & \end{array}$ & $\begin{array}{l}\text { Real-time reporting } \\
\text { is one of the aims of } \\
\text { this model. To this } \\
\text { end, information } \\
\text { must be collected } \\
\text { and monitored in } \\
\text { real-time }\end{array}$ & $\begin{array}{l}\text { Frequency of } \\
\text { analysis will depend } \\
\text { on the level of risk } \\
\text { and the degree to } \\
\text { which management } \\
\text { is monitoring the } \\
\text { controls. }\end{array}$ \\
\hline $\begin{array}{l}\text { Reporting } \\
\text { method }\end{array}$ & $\begin{array}{l}\text { Web-enabled data } \\
\text { delivery of data to } \\
\text { auditors' } \\
\text { workstations, where } \\
\text { reports can be } \\
\text { generated (possibly } \\
\text { by Generalized } \\
\text { Audit Software) }\end{array}$ & $\begin{array}{l}\text { Graded alerts sent } \\
\text { through } \text { Virtual } \\
\text { Private Networks, } \\
\text { (VPNs) to Audit } \\
\text { Department, }\end{array}$ & $\begin{array}{l}\text { Three levels of } \\
\text { reporting, alerts are } \\
\text { sent to the audit or } \\
\text { via email. Evergreen } \\
\text { reports are produced } \\
\text { on demand through } \\
\text { a web interface- } \\
\text { information pull } \\
\text { approach }\end{array}$ & $\begin{array}{l}\text { Prioritizes results } \\
\text { and determines the } \\
\text { frequency of the } \\
\text { continuous auditing } \\
\text { activities. } \\
\text { Runs the tests on a } \\
\text { regular, timely basis. }\end{array}$ \\
\hline
\end{tabular}

Source: Canadian institute of chartered accountants.

\section{Methodology}

Survey method using questionnaires was used to collect data from the target population for 400 auditors in the Public Sector Audit Organization who perform the financial audits of the Nigeria's federal government, Local Government and State Government. This descriptive method enhanced continuous auditing in the public sector. A total of 100 auditors participated and this sample fulfilled the requirements of efficiency, representativeness, reliability and flexibility.

The key questions posed to the respondents included: Extent to which business systems and processes are automated; Amount of data in business system that was in auditable format, extent of the availability of data extraction and analysis tools; skills and knowledge possessed by the auditors; existence of adequate information technology infrastructure for continuous auditing.

Data collected was analyzed using SPSS and Excel. In addition the Audit Command Language (ACL) software and a database system of a government ministry were used to demonstrate how data can be obtained directly from client system and audited shortly after the transactions take place.

The research design logically linked the data that was collected and the conclusions drawn and to the initial questions of a study so as to ensure coherence. The design was an action plan for getting from the questions to conclusions. This ensured that the concept of Continuous Auditing was made clear and provided a model of how it can be implemented in the Public Sector Audit Organization. 


\section{Result and Discussion}

The results are discussed in five categories: Business Systems and Processes; Auditable Data Format; Data Extraction and Analysis Tools; Data Analysis Knowledge and Skills; and Information Technology Infrastructure. Table 2 represents an aggregate of the categories.

Table-2. Summary of Responses on Continuous Auditing.

\begin{tabular}{l|l|l|l|l|l}
\hline $\begin{array}{l}\text { To what extent do you agree with the } \\
\text { following statements regarding continuous } \\
\text { auditing in the organization }\end{array}$ & $\begin{array}{l}\text { Strongly } \\
\text { Disagree }\end{array}$ & Disagree & Neutral & Agree & $\begin{array}{l}\text { Strongly } \\
\text { Agree }\end{array}$ \\
\hline Automation of Business Systems and processes & 2.6 & 39.5 & 18.4 & 32.9 & 6.6 \\
\hline Auditable of Data Format & 6.6 & 15.8 & 13.2 & 52.6 & 11.8 \\
\hline $\begin{array}{l}\text { Availability of Data extraction and Analysis } \\
\text { tools }\end{array}$ & 21.1 & 31.6 & 14.5 & 26.3 & 6.6 \\
\hline Auditor Data Analysis Knowledge and Skills & 11.8 & 25 & 28.9 & 30.3 & 3.9 \\
\hline IT Infrastructure for Continuous Auditing & 11.8 & 46.1 & 18.4 & 23.7 & 0 \\
\hline Source: Canadian institute of chartered accountants & & &
\end{tabular}

$39.5 \%$ of the respondents agreed that business systems and processes were automated while $42.1 \%$ disagreed. Business systems are processes automation is a key consideration necessary for implementation of continuous auditing format $64.4 \%$ agreed. This suggests that auditors would be able to perform audit procedures soon after obtaining the data without having to perform data cleaning and conversion. Further, the respondents were asked the extent for the availability of data extraction and analysis tools where $52.7 \%$ disagreed. This means access to the tools was very low. This was followed by the question on whether the auditors possessed skills and knowledge in use of these tools in which $36.8 \%$ disagreed. This indicates that there is need for more training in use of Computer Aided Tools for the auditors. Finally, 57.6\% of the respondents disagreed on the existence of adequate Information Technology infrastructure for continuous auditing suggesting the need for Public Sector Audit Organization to invest in information Technology resources in order to realize continuous auditing.

The research sought to find the control measures and risk management models put in place by the management. This is an important constitution for implementation of continuous auditing. Table 3 summarizes three components. Adequate System Control Measures. Efficient Internal Control and Processes. Risk Assessment Model.

Table-3. Summary of responses on continuous controls and risk assessment

\begin{tabular}{l|l|l|l|l|l}
\hline $\begin{array}{l}\text { To what extent do you agree on the } \\
\text { existence of the following }\end{array}$ & $\begin{array}{l}\text { Strongly } \\
\text { Disagree }\end{array}$ & Disagree & Neutral & $\begin{array}{l}\text { Agree } \\
\text { Agree }\end{array}$ \\
\hline Adequate System Control Measures & 1.3 & 11.8 & 36.8 & 46.1 & 3.9 \\
\hline Efficient Internal Controls and Processes & 5.3 & 25 & 39.5 & 26.3 & 3.9 \\
\hline Risk Assessment Model & 5.3 & 48.7 & 23.7 & 22.4 \\
\hline
\end{tabular}

Source: Canadian institute of chartered accountants.

The results indicate that $50 \%$ of the respondents indicated that there exist controls within the clients' systems. It further indicated $36.8 \%$ of responses were neutral about existence of controls. Those who did not agree on existence of the controls formed only $13.1 \%$. There is therefore a strong indication that the system in place have adequate controls. In regard to risk assessment, majority of the respondents (65\%) indicated that there were no existing risk assessment models in the client's organization. This suggests that the role of identifying the risk area within the organization has not been prioritized.

\section{Conclusion}

The study found out that time is ripe for continuous auditing to be implements in the Public Sector Audit Organization in Nigeria since most of the requirements for it are already in existence. With the advancement being made in technology and the changes in the Nigerian government financial management system, the use of continuous auditing is an important paradigm shift which will enable the auditors to remain relevant and cope with these changes. With the increasing automation of business processes, the use of continuous auditing can increase efficiency in the Public Sector Audit Organization. There would be tangible benefits that would result in the use of continuous auditing and hence enable the office to carry on it mandate effectively and with ease. The findings indicated that there as a low level of training in the skills necessary for continuous auditing among the respondents. It is therefore recommended that training needs in future should incorporate these skills and knowledge. In addition, the study revealed that there was no adequate investment in IT resources and infrastructure. It is therefore important to consider improvement in their resources in future in order to realize continuous auditing. 
Further research work needs to explore the use of intelligent agents in conducting audit. The use of these agent to detect unusual activities or unexplained activity patterns and alert the auditor would play a great role in changing the way audit is done. There is need for the development and implementation of tailor made continuous auditing software tools that would encompass all the required functions of continuous auditing.

\section{References}

CICA/AICPA. (1999). Continuous auditing research report. Canadian Institute for Chartered Accountant and American Institute of Certified Public Accountants.

Groomer, M., \& Murthy, U. (1989). Continuous auditing of database accounting system using embedded audit modules. Journal of Information System, 3(1), 53-61.

Rezaee, Z., Sharbatoghile, A., Elam, R., \& McMickle, P. (2002). Continuous auditing: Building automated auditing capacity. Auditing: A Journal of Practice and Theory, 21(1), 147-163.

Shields, G. (1998). Non-stop auditing. CA Magazine, 39-40.

Vasarhelyi, M., \& Halper, F. (1991). The continuous audit of on-line system, auditing. A Journal of Practice and Theory, 10, $110-124$. 